\title{
AN EX POST EVALUATION OF THE CONTRIBUTIONS OF IRRIGATION TO REGIONAL DEVELOPMENT IN ALBERTA: A CASE STUDY*
}

\author{
Surendra N. Kulshreshtha and K. Dale Russell**
}

Conventionally, contributions of an industry are measured in terms of its direct impacts on a regional economy. Such direct impacts include returns or valueadded activities, employment of resources, contributions to foreign trade, among others. It is the thesis of this study that such measures of direct impacts tend to underestimate the total contribution of an industry to the region. Impacts upon a regional economy include not only these direct impacts, but also secondary impacts. An interindustry comparison of direct plus secondary contributions is one way to demonstrate total regional level impacts. Since any policy development based simply on the direct contributions of an industry may not lead to a socially optimum allocation of resources, estimation of total impacts is necessary for developing optimum social policies for regional development.

Irrigation development in the prairie provinces generally, and particularly in Alberta, has been criticized on the grounds that its benefits are directed to a small sector of the provincial economy. This type of criticism implicitly assumes that the contributions of irrigation stop at the farm gate, that either society at large does not benefit from the irrigation industry or all economic activities generate similar socio-economic impacts on society in the region.

Any industrial activity in a given region, by virtue of its purchases and sales pattern, gives rise to secondary impacts. Evaluation of public sector, as well as private sector, decisions requires an evaluation of these probable secondary regional effects. Regional impacts of a given policy/program may encompass both economic and noneconomic effects. The latter present problems of quantification. Major economic impacts can be measured through the use of various types of models, although input-output models are particularly designed to capture secondary market impacts of specified economic stimuli.

In the past, input-output models have been used to predict the impacts of a change in some policy program, of an investment in an additional facility, on the regional

\footnotetext{
*Financial assistance was provided for this research by the Alberta Irrigation Projects Association, which is gratefully acknowledged. (Many valuable comments were received from two anonymous reviewers of this Joumal.)

**Respectively, professor of agricultural economics, University of Saskatchewan; and agricultural and resource Economist, UMA Engineering Ltd., Lethbridge.
}

economy. Such models also have been used to determine the regional impact of a new industry or firm moving into the region. This latter situation also can be improvised to determine the secondary contributions made by an existing industry.

\section{Objectives of the Study}

The primary objective of this study was to use an input-output model in determining the ex post contributions of irrigation development in southern Alberta. Specifically, this study was designed to: estimate the contributions of irrigated agricultural production to the provincial economy of Alberta; determine the direct and indirect employment of labour resources as a result of irrigated agriculture; and estimate the effect of irrigated agriculture on the generation of government revenues.

The study was carried out for the year 1981. The choice of the year was determined by availability of data. ${ }^{1}$ An updated input-output model was linked with an employment production function and a government revenue model.

\section{Conceptual Model}

In any economy, an economic stimulus gives rise to several types of changes in the economic system. These can be classified broadly into changes in market activities and changes in activities not captured by market forces. The latter include changes in demographic and social characteristics, environmental quality, and in government and legal institutions. For the sake of this study, these nonmarket secondary effects are assumed to exist, but are not quantified.

Secondary market effects (i.e., the changes in an economy as a result of an economic stimulus) include the second, third, fourth, et seq., rounds of economic ripples created by the initial stimulus. These ripples are created by forward and backward linkages between and among firms, between firms and consumers, and other purchasers of goods and services. The backward linkages give rise to increased economic activity through interindustry interdependencies, as well as through the payments to the labour sector, part of which finds its way back into the economy. Since a portion of input requirements for various industries 
is obtained from industries located outside the regional boundaries, these outside regions also experience increased economic activity. The ripple impacts are partly due to the forward linkages and thus to changes in the outputs of industries that use the products of the primary impact industry as inputs to their production processes. All of the above impacts are referred to as secondary impacts. In addition to the impact of the purchases of other industries on a given industry, secondary impacts also may be generated by consumer purchases. The consumers, as owners of resources, receive more compensation for increased economic activities. These higher incomes are translated partially into the purchase of goods and services, and partially into government revenues, through direct and indirect taxes. Thus, another set of ripple effects can be hypothesized to be created by increased consumer spending.

Both the industrial support and consumer impacts included in secondary effects are estimated through the input-output model, although each of them may be segregated, if so desired. In addition to the above two types of impacts, another impact can be identified. This may be referred to as the industry scale effect. Over time, many new industries and firms may be attracted to the region, further strengthening the backward linkage effects upon the regional economy. This latter type of effect is known as the agglomeration effect. As changes in an industry continue over a period of time and, thus, increases in magnitude, opportunities are created for a number of related industries to move into a region. These opportunities are a result of factors related to the economics of production (i.e., it has become more economical for firms to procure their inputs and market their products from a new location). Identification of such industries is a key step in the ex post evaluation of the contributions of the sector to society.

In addition to market activity related impacts, there are several other types of economic impacts that are implied, but are not captured directly by input-output models. Two types of impacts, not captured directly by the inputoutput model, were considered important to the study. One of these is employment levels generated by irrigation activities. With concern over unemployment and given the present level of underemployment in the Alberta economy, it is important to determine how employment opportunities are enhanced within the regional economy. The second is contributions to government revenues. Irrigation projects typically require large amounts of joint public-private funding, and since part of the initial investment is contributed by public treasuries, it is important to estimate how much of that expenditure is recovered by the provincial treasury during the life of the project.

\section{Study Procedure: Empirical Model}

As mentioned above, this study was designed to capture the ex post contributions, direct as well as secondary impacts, of irrigation in southern Alberta. The adopted method provided for the measurement of direct and indirect effects of irrigation on economic activities, employment levels, and government revenues. This involved the development and interfacing of the following four types of models:

1. Rehabilitation Expenditures Simulator (RES),

2. Farm Level (Irrigated Agriculture) Simulator,

3. Input-Output Model (I-O), and

4. Ancillary Models
a. Employment Model, and
b. Government Revenue Model.

The relationship and linkages among these models are shown in Figure 1. The purpose of developing the RES model was to predict the nature of changes in irrigated agriculture resulting from an increase (or a decrease) in the Irrigation Capital Works program expenditures. These expenditures have a direct impact on the farmers and the irrigation districts that serve these farmers. The direct influence of a change in the capital works rehabilitation programs has been aggregated into three categories: acres of land that can be irrigated, probable level of yield that can be obtained, and the costs of irrigation system maintenance borne by the irrigation district. The farm level simulator was designed to estimate the nature and level of purchases and production of agriculture on dryland and irrigated land during 1981. Furthermore, this model also was used to predict the relative change in the output and purchases of the agriculture industry, if there were no irrigation in southern Alberta.

The input-output model used in this study was of a rectangular nature. ${ }^{2}$ It contained a total of 47 industries and 90 intermediate commodities. In addition, four types of primary inputs and four types of imports were identified. ${ }^{3}$ The households were endogenized, adding one industry and two commodities to the intermediate inputs. The model was manipulated to yield sector (industry) output. ${ }^{4}$

$$
G=D[(I-\hat{\mu}-\hat{\alpha}) B] G+D[I-\hat{\mu}-\hat{\alpha}] F+D[I-\hat{\alpha}] X,
$$

where

$\mathrm{G}=\mathrm{a} 48 \times 1$ vector of industry output,

$D=\mathrm{a} 48 \times 92$ matrix of market share coefficients,

$\mathrm{B}=\mathrm{a} 92 \times 48$ matrix of industry technological coefficients, 
Linkages Among Various Model Components

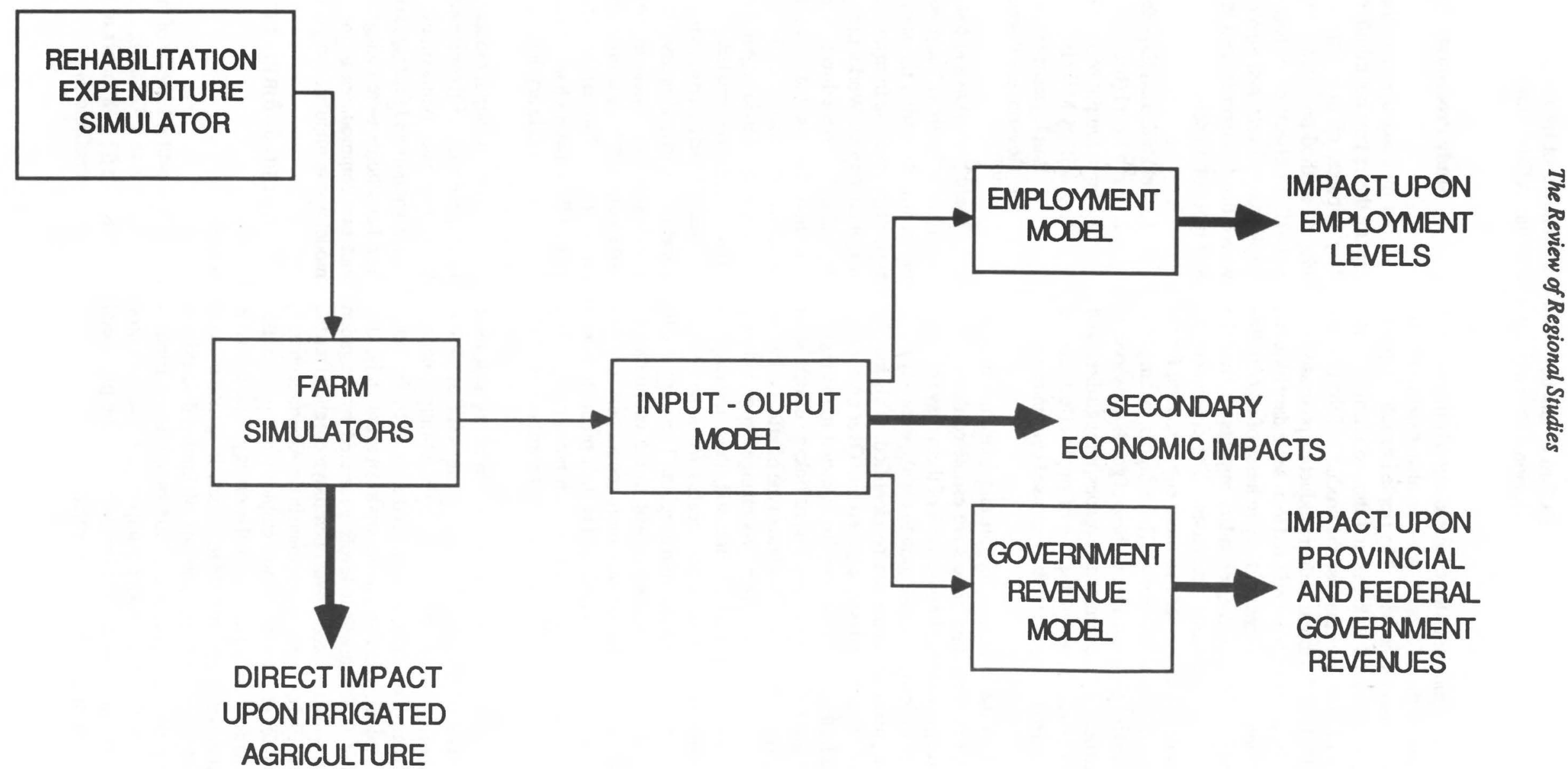


An Ex Post Evaluation of the Contributions of Irrigation to

Regional Development in Alberta: A Case Study

$\hat{\mu}=$ a diagonal matrix $(92 \times 92)$ of import to total use ratios,

$\hat{\alpha}=a$ diagonal matrix $(92 \times 92)$ of other leakageto-use ratios,

F = final demand by commodities, excluding households and exports, and

$\mathrm{X}=$ exports by commodity .

Equation 1 can be solved in terms of sector output $G$ as:

$$
G=[I-D(I-\hat{\mu}-\hat{\alpha}) B]^{-1}[D(I-\hat{\mu}-\hat{\alpha}) F+D(I-\hat{\alpha}) X]
$$

Original data for the provincial input-output model were obtained from the Alberta Bureau of Statistics for the year $1974 .^{5}$ This was the latest year for which a transactions table was available. Since such a table was considered nonrepresentative of the structure of the current Alberta economy, it was updated. The most current data available for all components of the Alberta economy for this analysis were for the year 1981. Recall from Equation 1 above that $[D(I-\hat{A}-\hat{\alpha}) \mathrm{B}]$ is a $48 \times 48$ matrix. This square matrix was updated by the RAS method. ${ }^{6}$ A condensed version of the transactions table is shown in Table 1 . In this version, the irrigated agriculture sector is separated out. ${ }^{7}$ During 1981 , it produced $\$ 683$ million worth of goods and services. In direct contributions, irrigated production contributed $\mathbf{1 8 . 2}$ percent of the total agricultural production, but only 0.7 percent of the total industrial output in the province.

Increased economic activity, as measured by the indirect impacts, is reflected in two other changes in the regional accounting framework. One is the increased number of jobs created by the indirect and induced effects of irrigation development. The other is changes in the revenues received by various levels of government from the increased economic output and household incomes. The first type of change is captured through the development of an employment model. The second change is estimated through a government revenue model.

The employment model was conceptualized in terms of the well-known employment production function suggested by Moore and Peterson, particularly since the use of employment coefficients is equivalent to the notion of employment multipliers. ${ }^{8}$ Labour employment $\left(L_{i}\right)$ in the $i^{\text {th }}$ sector $(i=1, \ldots, S)$ during the $t^{\text {th }}$ year $(t=1, \ldots, n)$ is expressed as:

$$
L_{i t}=\alpha+\beta g_{i t}+q_{i t},
$$

where

$$
\begin{aligned}
& \mathrm{g}_{\text {it }}=\text { output of the } \mathrm{i}^{\text {th }} \text { industry during the } \mathrm{t}^{\text {th }} \\
& \text { period, }
\end{aligned}
$$

$$
\begin{aligned}
& \alpha \text { and } \beta=\text { parameters to be estimated; and } \\
& e_{i t}=\quad \text { a random variable, satisfying all } \\
& \text { assumptions of the classical least } \\
& \text { squares estimation procedure. }
\end{aligned}
$$

Data for the period 1971 to 1981 were used in the estimation of these functions. In certain instances, time series data on output for a particular sector were not available. In these situations, time series data on gross domestic product were used and the 1981 ratio of gross domestic product and value of output for that sector was utilized to estimate the employment production function. Estimated coefficients for the employment production functions are shown in Table 2. The wholesale and retail trade sectors are based on the commodity margins.

According to these estimates, the most labour intensive industries are miscellaneous manufacturing, the accommodation and food industry, the health and hospital industry, and business services, followed by the electrical products industry.

The government revenue model was specified by splitting the governments into two groups-federal government and provincial plus local government. The federal government revenues were disaggregated as follows:

$$
\begin{aligned}
& \text { FREV }_{t}=\text { FDTXH }_{t}+\text { FDTXB }_{t}+\text { FDTXNR }_{t}+ \\
& \text { FIDTX }_{t}+\text { FTRANS }_{t}+\text { FINVI }_{t}+\text { FOEXT }_{t}
\end{aligned}
$$

where

$$
\begin{aligned}
& t \text { subscripts }=\text { time period, } \\
& \text { FREV = total federal government revenue } \\
& \text { generated in Alberta, } \\
& \text { FDTXH = federal government direct taxes paid } \\
& \text { by Alberta households, } \\
& \text { FDTXB = federal government direct taxes paid } \\
& \text { by Alberta businesses, } \\
& \text { FDTXNR = federal government taxes paid by } \\
& \text { non-residents, } \\
& \text { FIDTX = federal government indirect taxes, } \\
& \text { excluding oil export tax, } \\
& \text { FTRANS = transfer by Alberta people (house- } \\
& \text { holds) to the federal government, } \\
& \text { FINVI = federal government investment in- } \\
& \text { come, and } \\
& \text { FOEXT = federal government export tax on } \\
& \text { crude oil exported out of Alberta. }
\end{aligned}
$$

Similar provincial and local government revenues in Alberta were disaggregated as follows:

$$
\begin{aligned}
& \text { PREV }_{t}= \text { DTXH }_{t}+\text { DTXB }_{t}+\text { DTTX }_{t}+ \\
& \text { TRANSH } \\
& t
\end{aligned}
$$


Table 1

Input-Output Structure of the Alberta Economy, 1981 (millions of dollars)

\begin{tabular}{|c|c|c|c|c|c|c|c|c|c|c|c|c|c|}
\hline $\begin{array}{l}\text { Producing/Purchasing } \\
\text { Particulars }\end{array}$ & $\begin{array}{l}\text { Dryland } \\
\text { Agriculture }\end{array}$ & $\begin{array}{c}\text { Irrigated } \\
\text { Agriculture }\end{array}$ & $\begin{array}{l}\text { Primary } \\
\text { Resources }\end{array}$ & $\begin{array}{l}\text { Agriculture } \\
\text { Processing }\end{array}$ & $\begin{array}{l}\text { Non-Agriculture } \\
\text { Manufacturing }\end{array}$ & $\begin{array}{l}\text { Construction } \\
\text { and Irrigation }\end{array}$ & Trade & $\begin{array}{c}\text { Transporta- } \\
\text { tion }\end{array}$ & Finance & Services & $\begin{array}{c}\text { Household } \\
\text { Consumption }\end{array}$ & Exports & $\begin{array}{c}\text { Other Final } \\
\text { Demands }\end{array}$ \\
\hline Dryland Agriculture & 92.6 & 8.9 & 1.8 & $1,613.5$ & 9.0 & 3.5 & 166.6 & 1.8 & 0.8 & 106.6 & 297.9 & 870.1 & 1.5 \\
\hline Irrigated Agriculture & 31.2 & 3.0 & 0.4 & 487.8 & 1.5 & 0.7 & 35.1 & 0.4 & 0.2 & 22.5 & 62.7 & 83.5 & 0.3 \\
\hline Primary Resources & 3.7 & 5.6 & 693.7 & 36.1 & $3,311.7$ & $1,515.8$ & 55.4 & 420.7 & 80.5 & 71.5 & 337.2 & $19,540.1$ & 529.3 \\
\hline Agriculture Processing & 178.4 & 83.1 & 11.2 & 333.1 & 37.0 & 30.9 & 4.6 & 1.1 & 0.8 & 588.4 & $1,936.8$ & 533.6 & 19.0 \\
\hline Non-Agriculhure Manufacturing & 218.5 & 43.2 & 446.8 & 88.3 & $1,182.9$ & $2,172.8$ & 240.6 & 516.9 & 92.5 & $1,007.4$ & $1,899.1$ & 432.6 & $1,351.8$ \\
\hline $\begin{array}{l}\text { Construction and Irrigation } \\
\text { Construction }\end{array}$ & 7.2 & 5.0 & 862.2 & 4.1 & 26.8 & 5.5 & 18.1 & 160.4 & 885.4 & 11.5 & 5.8 & 0.0 & $11,204.4$ \\
\hline Trade & 4.5 & 1.5 & 112.5 & 134.6 & 333.1 & 524.2 & 42.5 & 85.2 & 20.4 & 545.0 & $1,869.9$ & 221.6 & $1,652.3$ \\
\hline Transportation & 184.2 & 53.9 & 591.4 & 91.3 & 288.5 & 356.4 & 381.2 & $1,970.1$ & 277.0 & 633.3 & $1,683.5$ & 427.6 & 369.5 \\
\hline Finance & 522.6 & 85.0 & $7,112.3$ & 13.8 & 84.4 & 160.0 & 351.1 & 113.0 & 925.6 & 379.5 & $2,794.8$ & 5.3 & 696.8 \\
\hline Services & 109.8 & 32.6 & $1,871.0$ & 108.5 & 368.2 & 930.8 & 537.4 & 428.7 & 916.3 & $1,471.4$ & $3,340.2$ & 8.2 & 641.9 \\
\hline Household Income & 731.4 & 167.1 & $2,625.0$ & 288.6 & $1,501.7$ & $3,942.8$ & $2,756.8$ & $1,854.1$ & $2,158.9$ & $3,322.8$ & 617.7 & 0.0 & $2,392.3$ \\
\hline Non-competitive Imports & 0.0 & 0.0 & 0.0 & 0.1 & 281.1 & 0.0 & 2.0 & 0.0 & 0.0 & -146.7 & 576.5 & -557.5 & 1.0 \\
\hline Indirect Tax Less Subsidy & 70.6 & 14.4 & 386.9 & -3.4 & -16.1 & 331.4 & 62.0 & 118.6 & 737.0 & 163.8 & 316.0 & 868.1 & 329.4 \\
\hline Other Operating Surplus & 573.2 & 51.9 & $10,017.9$ & 110.0 & 730.9 & 649.7 & 557.3 & $1,147.3$ & $6,659.3$ & 915.6 & 28.2 & 0.0 & 212.3 \\
\hline Competitive Imports & 470.9 & 102.3 & $1,140.1$ & 367.4 & $1,348.4$ & $2,189.8$ & 155.8 & 283.3 & 108.8 & $1,351.8$ & $4,248.0$ & 568.0 & $5,642.5$ \\
\hline Residuals & -3.1 & 35.7 & 364.1 & 42.2 & 133.6 & 191.3 & 90.4 & 103.3 & 190.4 & 160.3 & $1,163.2$ & 0.0 & 0.0 \\
\hline Totals & $3,177.7$ & 693.4 & $26,237.4$ & $3,715.8$ & $9,559.6$ & $13,005.1$ & $5,457.0$ & 7,2048 & 13,0538 & $10,604.8$ & $21,177.5$ & $23,501.6$ & $25,044.3$ \\
\hline TOTAL ECONOMIC OUTPUT: & & $92,706.0$ & & & & & & & & & & & \\
\hline
\end{tabular}


An Ex Post Evaluation of the Contributions of Imigation to

Regional Development in Alberta: A Case Study

Table 2

Estimates for Employment Production Function for Alberta, 1981

\begin{tabular}{|c|c|c|c|c|}
\hline $\begin{array}{l}\text { Sector } \\
\text { Number }\end{array}$ & Description & $\alpha$ & $\beta$ & $\begin{array}{l}t \text {-value for } \\
\text { B Coefficient }\end{array}$ \\
\hline 1 & Dryland Agriculture & 51,718 & 0.0060 & 0.44 \\
\hline 2 & Forestry & 2,000 & 0.0 & - \\
\hline 3 & Fisheries, etc. & 0 & 0.0 & - \\
\hline 4 & Coal Mines & 0 & 0.0010 & 0.735 \\
\hline 5 & Petroleum Mines, etc. & 43,197 & 0.0010 & 0.735 \\
\hline 6 & Other Mines & 0 & 0.0010 & 0.735 \\
\hline 7 & Services to Mining & 0 & 0.0 & - \\
\hline 8 & Meat Processors & 2,591 & 0.0020 & 2.48 \\
\hline 9 & Poultry Processors & 213 & 0.0077 & 5.33 \\
\hline 10 & Dairy Factories & 2,875 & 0.0 & - \\
\hline 11 & Fruit and Vegetable Processing & 599 & 0.0020 & 0.11 \\
\hline 12 & Feed Manufacturers & 385 & 0.0026 & 12.12 \\
\hline 13 & Flour, etc. & 395 & 0.0005 & 2.32 \\
\hline 14 & Miscellaneous Food & 1,903 & 0.0049 & 12.94 \\
\hline 15 & Beverage & 1,977 & 0.00004 & 0.027 \\
\hline 16 & Rubber & 288 & 0.0103 & 5.60 \\
\hline 17 & Leather & 216 & 0.0014 & 0.483 \\
\hline 18 & Textile & 416 & 0.0061 & 3.04 \\
\hline 19 & Clothing & 1,833 & 0.0011 & 0.08 \\
\hline 20 & Wood & 3.776 & 0.0065 & 1.90 \\
\hline 21 & Fumiture & 765 & 0.0108 & 2.93 \\
\hline 22 & Paper & 514 & 0.0054 & 13.15 \\
\hline 23 & Printing & 880 & 0.0167 & 9.89 \\
\hline 24 & Primary Metal & 1,219 & 0.0042 & 3.60 \\
\hline 25 & Metal Fabricating & 1,158 & 0.0116 & 15.49 \\
\hline 26 & Machinery Industries & 674 & 0.0116 & 9.89 \\
\hline 27 & Transportation Equipment & 2,014 & 0.0073 & 12.74 \\
\hline 28. & Electrical Products & -784 & 0.0186 & 5.00 \\
\hline 29 & Non-Metal Products & 2,809 & 0.0039 & 1.97 \\
\hline 30 & Petroleum Products & 547 & 0.0004 & 4.05 \\
\hline 31 & Chemical Products & 1,422 & 0.0026 & 9.19 \\
\hline 32 & Miscellaneous Manufacturing & -458 & 0.0410 & 7.84 \\
\hline 33 & Dam and Irrigation & 58 & 0.0080 & 11.06 \\
\hline 34 & Other Construction & 5,348 & 0.0080 & 11.06 \\
\hline 35 & Wholesale and Retail Trade & 112,966 & 0.0183 & 6.32 \\
\hline 36 & Transportation & -932 & 0.0123 & 8.89 \\
\hline 37 & Communication & 0 & 0.0123 & 8.89 \\
\hline 38 & Utilities & 0 & 0.0123 & 8.89 \\
\hline 39 & Finance, etc. & 12,109 & 0.0037 & 8.89 \\
\hline 40 & Health and Hospital & 0 & 0.0310 & 6.89 \\
\hline 41 & Business Services & 0 & 0.0310 & 6.89 \\
\hline 42 & Accommodation and Food & $-10,532$ & 0.0330 & 20.53 \\
\hline 43 & Personal and Miscellaneous & $-2,428$ & 0.0123 & 6.89 \\
\hline 44 & Dummy Inchustry I & 0 & 0.0310 & 6.89 \\
\hline 45 & Dummy Industry II & 0 & 0.0310 & 6.89 \\
\hline 46 & Transportation Margins & 0 & 0.0123 & 8.89 \\
\hline 47 & Irrigated Agriculture & 13,585 & $0.0070^{*}$ & \\
\hline
\end{tabular}

- Not based on regression because of too few degrees of freedom 
where

$$
\begin{aligned}
t \text { subscripts = } & \text { time period, } \\
\text { PREV }= & \text { total provincial and local revenue, } \\
\text { DTXH } & \text { total direct taxes paid by house- } \\
& \text { holds } \\
\text { DTXB = } & \text { total direct taxes paid by businesses, } \\
\text { IDTX }= & \text { indirect taxes, } \\
\text { TRANSH = } & \text { transfers from people for services, } \\
& \text { particularly for licenses and medi- } \\
& \text { care, } \\
\text { TRANSG }= & \text { transfers from the federal govern- } \\
& \text { ment, and } \\
= & \text { investment income by various levels } \\
& \text { of provincial, local, and other public } \\
& \text { institutions. }
\end{aligned}
$$

Among various categories of federal government revenues, direct taxes from people and businesses were the highest ranking, whereas at the provincial level investment income was the highest. Each of these revenue variables, with the exception of federal government transfers from Alberta, investment income, and the export tax on crude oil, was explained by the level of economic activity in the province. The only exception to this was transfer payments to the Alberta province, which were explained by the relative performance of the Alberta economy (as compared with the average Canadian economy). However, in addition to this, per capita value-added may play an important role since certain sharing of federal-provincial programs is based on a combined population and value-added criteria. Data for the period 1964 to 1981 were used $^{9}$ and estimates were obtained using OLS. ${ }^{10}$ Results are shown in Table 3. All of the variables were measured in percent except for $X_{10}$, which was measured in units.

According to the above estimated results, for every dollar received by households as income, $\$ 0.07$ is received by the provincial government as direct taxes. Although it was hypothesized that as more people receive welfare, less household income accrues to provincial taxes, the estimated sign for this variable $\left(X_{2}\right)$ was negative, but lacked statistical significance. Direct taxes paid by businesses were found to be highly dependent on the level of business income $\left(X_{3}\right)$. For every dollar earned by business, an average of $\$ 0.034$ is received by the provincial treasury. Similar interpretaions can be attached to other variables.

The model(s) were validated for the year 1981 on the basis of economic output, value-added, employment levels, and government revenues. Although for some individual sectors or items, the discrepancy between actual and estimated was large, on aggregate such errors were very reasonable. Furthermore, discrepancy in irrigation and related sectors were less than 3.5 percent and were considered relatively small. The discrepancies in GDP and employment were 1.1 and 1.4 percent, respectively.

\section{Procedure for Estimating the Ex Post Contribution of Irrigation}

The ex post contribution of irrigated agriculture in Alberta during 1981 was evaluated by comparing the estimated magitudes of economic activities associated with no irrigation in the area to the current situation with irrigation. Since under the no irrigation scenario, rehabilitation expenditures were assumed to be zero, and since these expenditures were maintained at the current level under the existing irrigation scenario, changes at the farm level on account of no irrigation were made through the farm simulators. Dryland cropping activities replaced the irrigated production, and a new vector of agricultural production was created. This set of information was used to simulate the Alberta economy under no irrigation. These results were then compared with the situation that existed during 1981. The marginal contribution (MCN) of irrigation was:

where

$$
\mathrm{MCN}=\{\mathrm{Z}\}-\left\{Z^{*}\right\}
$$

$\mathrm{Z}=\mathrm{a}$ set of economic or related level of variables in 1981 , and

$\mathrm{Z}^{*}=\mathbf{a}$ corresponding set of variables in 1981 under no irrigation.

Since the removal of an existing sector represents a major structural change in the economy, several modifications are similar to those necessary to analyze the impacts of a new industry on a region as discussed by Isard and Kuene. However, there are several discrete differences. A new transactions table (DB) was created to reflect the nature of the economy with no irrigated agricultural production in the province. The new transactions table excluded all transactions by irrigated agriculture. In addition, all sectors whose economic activity levels would be harmed due to no irrigation also were adjusted. The identification of such sectors was based on their sales and purchase patterns. It was assumed that if an industry sold 75 percent or more of its output to the irrigated agriculture sector, it would not be able to survive under no irrigation. The irrigation construction sector was identified as such an industry. Similarly, if key intermediate inputs for an industry were produced by irrigated agriculture, under the no irrigation scenario the industry faces two alternatives: 
An Ex Post Evaluation of the Contributions of Irrigation to

Regional Development in Alberta: A Case Study

Table 3

Estimated Results for the Federal and Provincial Revenue Model, Alberta

\begin{tabular}{|c|c|c|c|c|}
\hline LHS Variable & Intercept & Regression Coefficients & $\mathbf{R}^{2}$ & D-W \\
\hline FDTXH & -121.34 & $\begin{array}{l}0.1588 \mathrm{X}_{1} \\
(42.6)\end{array}$ & 0.991 & 0.916 \\
\hline FDTXB & 59.53 & $\begin{array}{l}0.1059 X_{3} \\
(21.2)\end{array}$ & 0.966 & 0.848 \\
\hline FDTXNR & 2.34 & $\begin{array}{l}0.0037 \mathrm{X}_{3} \\
(24.0)\end{array}$ & 0.973 & 1.130 \\
\hline FIDTX & -10.83 & $\begin{array}{l}0.0277\left(X_{4}+X_{5}\right) \\
(37.6)\end{array}$ & 0.989 & 1.384 \\
\hline DTXH & -109.23 & $\begin{array}{l}0.7 X_{1}-\frac{0.025 X_{2}}{(3.6)} \quad(0.02)\end{array}$ & 0.992 & 1.550 \\
\hline DTXB & 16.13 & $\begin{array}{l}0.0342 \mathrm{X}_{3} \\
(20.8)\end{array}$ & 0.964 & 0.758 \\
\hline IDTX & 187.56 & $\begin{array}{l}0.045\left(X_{4}+X_{5}\right) \\
(30.3)\end{array}$ & 0.983 & 0.736 \\
\hline TRANSH & 6.99 & $\begin{array}{l}0.0567\left(X_{6}+X_{7}\right) \\
(13.8)\end{array}$ & 0.922 & 0.360 \\
\hline INVI & -346.5 & $\begin{array}{l}0.6558 \mathrm{X}_{8} \\
(25.5)\end{array}$ & 0.976 & 1.027 \\
\hline TRANSG & -798.9 & $\begin{array}{l}101.67 X_{9} \\
(24.4)\end{array}$ & 0.951 & 1.524 \\
\hline
\end{tabular}

where $X_{1}=$ total personal income before taxes (this variable includes wages and salaries, income of unincorporated nonfarm businesses, military pay, and income of farm operators from farming);

$\mathbf{X}_{2}$ = transfer payments to people by the provincial and/or federal govemment;

$\mathbf{X}_{3}=$ total business income;

$\mathbf{X}_{4}=$ total consumer expenditures on goods and services;

$\mathbf{X}_{\mathbf{f}}=$ total business capital formation value;

$\mathbf{X}_{\mathbf{6}}=$ consumer expenditures on health care;

$\mathbf{X}_{\mathbf{Y}}=$ consumer expenditures on transportation;

$X_{1}=$ gross domestic product of the mining sector in Alberta;

$X_{0}=$ ratió of Canadian to Alberta total gross domestic product; and

$\mathbf{X}_{10}=$ ratio of Canada and Alberta per capita gross domestic product.

Note: Numbers in parentheses are the $t$-values corresponding to the regression coefficients.

one, it could import these inputs from outside the region; and two, it can cease operations. The first alternative was not considered feasible in light of the bulky and perishable nature of goods produced by the irrigated agriculture sector. The agricultural processing sector, particularly fruits and vegetables processing and sugar (beet sugar) manufacturing, thus was determined to be totally dependent upon irrigated production."

A new market share matrix, $D$, and an industry technology matrix, $B_{0}$, were created, and a new set of multipliers was generated: 


$$
M_{0}=\left[I-D_{0}\left(I-\hat{\mu}_{0}-\hat{\alpha}\right) B_{0}\right]^{-1} D_{0}
$$

where

$$
\begin{aligned}
& M_{0}=\text { a diagonal matrix resulting from the structural } \\
& \text { change in the economy. }
\end{aligned}
$$

The next step in the modification of the impact analysis procedure was to determine the final demand under the no irrigation production scenario. Adjustments were made in the exports of products produced by irrigated agriculture in proportion to its contribution to the total. Similarly, final demand for any industry whose output levels were changed in the new transactions table was adjusted by the magnitude of change in output level.

The changes in intermediate demand and final demand resulted in new import-to-use coefficients $-\mu_{0}$, which were used in the computation of the new sector multipliers (as in Equation 7) and in new final demand$[I-\hat{\mu}-\hat{\alpha}] F_{0}$.

The contribution of irrigation was estimated by subtracting from the 1981 actual numbers, corresponding estimated total sectoral outputs, value-added, employment levels, and federal and provincial government revenues. The contribution to sectoral output was:

$$
\begin{aligned}
G= & {[I-D(I-\hat{\mu}-\hat{\alpha}) B]^{-1} D[I-\hat{\mu}-\hat{\alpha}] F-} \\
& {\left[I-D_{0}(I-\hat{\mu}-\hat{\alpha}) B_{0}\right]^{-1} D_{0}[I-\hat{\mu}-\hat{\alpha}] F_{0} }
\end{aligned}
$$

with all terms defined as above.

Contributions to value-added (VA) and employment (EMP) were estimated as:

$$
\begin{aligned}
& \Delta V A=\left(V M D^{*} F\right)-\left(V_{0} M_{0} D^{*} F_{0}\right) \\
& \Delta E M P=E\left(M D^{*} F M_{0} D_{0}^{*} F_{0}\right.
\end{aligned}
$$

where

$$
\begin{array}{ll}
\mathbf{V} & =\text { a matrix of coefficients for primary inputs } \\
& \text { by sector, } \\
\mathbf{M} & =\text { a sector by sector multipliers matrix, } \\
\mathrm{D}^{*} & =\mathrm{D}[\mathrm{I}-\hat{\mu}-\hat{\alpha}] \\
\mathrm{F} \text { and } \mathrm{F}_{0}= & \text { original and new final demand by commodi } \\
& \text { ties, } \\
\mathrm{D}^{*} \cdot & =\mathrm{D}_{0}\left[\mathrm{I}-\hat{\mu}_{0}-\hat{\alpha}\right] \\
\mathbf{M}_{0} & =\text { as defined in equation }(7) \text { above, and } \\
\mathbf{E} & =\text { employment coefficients matrix. }
\end{array}
$$

Calculations were made similarly for government revenues.
As irrigation in Alberta increases (or decreases), the economic impact will be realized in many forms. Three areas of impact identified in this study are: level of gross economic activity (total value of goods and services produced) in Alberta and other regions of Canada, employment in Alberta, and government revenues to local and provincial governments, as well as those received by the federal government from the Province of Alberta.

The impacts on other regions of Canada were approximated by the following procedure. ${ }^{12}$ The imports of various products were estimated through the input-output model. That proportion of total imports originating from other Canadian regions was identified. According to Statistics Canada, ${ }^{13}$ Alberta obtained 64.2 percent of its imports from Canadian points in 1979. This proportion was used as a basis for dividing all imports in the province into those from Canadian points and those from outside of Canada. Since an import into Alberta is a final demand in the originating region, the import would have a valueadded impact on that region.

Although this procedure underestimates the effects on non-Alberta Canadian regions by the magnitude of the second generation impacts triggered by the higher imports resulting from irrigation, it does give an indication of the magnitude of these impacts. For example, a higher import into Alberta could trigger economic activity, in Ontario. But in Ontario, in order to produce the product, it might be necessary to import some products, from Manitoba. This latter impact is ignored in the estimates in this study and the estimated impacts on other Canadian regions may have been underestimated.

\section{Empirical Results}

The following discussion of the contributions of irrigation is presented in terms of economic activity i.e., value of goods shipped, value-added, employment, and government revenue. Economic activity in Alberta would be reduced by about $\$ 2,492$ million 1981 dollars if there were no irrigation in southern Alberta. This would amount to about 2.6 percent of all economic output generated in Alberta during 1981, Table 4.

In terms of provincial gross domestic product (at market prices), about $\$ 940$ million or about two percent of the 1981 level can be attributed to irrigation. The impact of irrigation development in Alberta on other Canadian regions has been estimated to be $\$ 304$ million worth of imported goods and services.

Some 35,000 full-time equivalent jobs in Alberta are associated directly or indirectly with irrigation, Table 5. About 19,000 of these jobs are in agricultural production. Almost 16,000 of the jobs in the services, transpor- 
Table 4

Impact of Irrigation on The Alberta Economy

\begin{tabular}{lccc}
\hline \hline & \multicolumn{3}{c}{ Revenue Level in 1981 (millions of dollars) } \\
\cline { 3 - 4 } Item & $\begin{array}{c}\text { With } \\
\text { Irigation }\end{array}$ & $\begin{array}{c}\text { Without } \\
\text { Irigation }\end{array}$ & $\begin{array}{c}\text { Marginal } \\
\text { Contribution } \\
\text { of Irrigation }\end{array}$ \\
\hline Total Sector Economic Activity* & 95,447 & 92,955 & 2,492 \\
Gross Domestic Product & & & \\
$\quad$ Household Income & 22,887 & 22,352 & \\
$\quad$ Net Indirect Taxes & 2,239 & 2,188 & 940 \\
$\quad$ Operating Surplus & 22,065 & 21,711 & 474 \\
$\quad$ Total GDP & 47,191 & 46,251 & 304 \\
Total Imports* & 18,918 & 18,444 & 11,841 \\
Imports from Other Provinces & 12,145 & 145 & \\
\hline \hline
\end{tabular}

*Excludes household sector, but includes all secondary-induced and stemming-from-impacts.

tation, and trade sectors also are directly and/or indirectly linked to irrigation. These jobs are related to irrigation because: (1) other non-agricultural sectors require products from irrigated agriculture as inputs to their production. These include industries such as fruit and vegetable processing, and the Alberta sugar industry; and (2) irrigated agriculture requires more and a greater variety of purchased inputs than are produced locally. Thus, if irrigated agriculture did not exist, many of these supply industries would have lower sales and lower levels of employment.

Irrigation development in southern Alberta contributes, directly and indirectly, roughly $\$ 276$ million annually to all levels of governments, local, provincial, and federal. ${ }^{14}$ About $\$ 164$ million per annum are received by the Alberta treasury through the increased economic activity resulting from irrigation development (Table 6). Of this, $\$ 85$ million are collected through taxes, while the rest results from investment incomes and transfers from people and other levels of government. Similarly, the federal govemment collects an additional $\$ 125$ million annually in personal, business, and non-resident taxes.

As explained above, federal government revenues are underestimated because the study excluded economic activity (and thereby contributions to federal revenues) resulting from the first and subsequent rounds of imports into the Alberta economy. It is obvious that total contributions of irrigated agriculture far exceed its direct contributions. The relative magnitude of these contributions is summarized in Table 7. The output multiplier for irrigation is estimated at 3.6, that is, for every dollar of production activity in irrigated agriculture, another $\$ 2.60$ worth of goods is produced by other sectors of the economy. The largest contribution of irrigation appears to be in indirect imports from the rest of Canada. Irrigation triggers demands for $\$ 3.65$ worth of imported products through other sectors for every dollar of imports by irrigation. Consequently, the benefits of irrigation in Alberta spill over to the other provinces of Canada. ${ }^{15}$

\section{Summary and Conclusions}

The primary objective of this study was to measure the contributions made by irrigation in southern Alberta to the provincial economy. Results suggest that these contributions extend far beyond the farm gate. About $\$ 940$ million of value-added (or two percent of the provincial total) is generated by the irrigation sector. Almost 35,000 full-time jobs in the province are directly and/or indirectly created by irrigation activities; thus, approximately three out of 100 workers depend upon irrigated agriculture, either directly or indirectly. The irrigation industry, through increased economic activity in the region, also contributes to federal, provincial, and local government revenues. This provides another round of ripple effects in the economy through increased government expenditures. Thus, investment in the irrigation infrastructure has yielded economic activity that has continued and would continue over a considerable period of time.

The results of this study suggest that contributions of a primary resource sector generally are higher than those 
Table 5

Impact of Irrigation on Alberta Employment, 1981

\begin{tabular}{|c|c|c|c|}
\hline \multirow[b]{2}{*}{ Sector } & \multicolumn{3}{|c|}{ Employment Level (Number of Workers Per Year) } \\
\hline & $\begin{array}{c}\text { With } \\
\text { Irrigation }\end{array}$ & $\begin{array}{l}\text { Without } \\
\text { Imigation }\end{array}$ & $\begin{array}{l}\text { Marginal } \\
\text { Contribution } \\
\text { of Irrigation }\end{array}$ \\
\hline Agriculture & 90,040 & 70,906 & 19,134 \\
\hline Other Primary Resources & 70,485 & 70,345 & 140 \\
\hline Agricultural Processing & 21,165 & 19,696 & 1,469 \\
\hline Other Manufacturing & 77,908 & 77,021 & 887 \\
\hline Construction & 111,902 & 110,359 & 1,543 \\
\hline Trade & 211,551 & 209,803 & 1,748 \\
\hline Transportation & 91,882 & 89,199 & 2,683 \\
\hline Finance & 62,881 & 61,950 & 931 \\
\hline Services & 294,552 & 287,983 & 6,565 \\
\hline Total & $1,032,367$ & 997,261 & 35,106 \\
\hline
\end{tabular}

Table 6

Impact of Irrigation on Government Revenues, 1981

\begin{tabular}{|c|c|c|c|}
\hline \multirow[b]{2}{*}{ Item } & \multicolumn{3}{|c|}{ Revenue Level (millions of dollars) } \\
\hline & $\begin{array}{l}\text { With } \\
\text { Irrigation }\end{array}$ & $\begin{array}{l}\text { Without } \\
\text { Inigation }\end{array}$ & $\begin{array}{l}\text { Marginal } \\
\text { Contribution } \\
\text { of Irrigation }\end{array}$ \\
\hline \multicolumn{4}{|c|}{$\begin{array}{l}\text { Alberta and Local Governments } \\
\text { Direct Taxes }\end{array}$} \\
\hline People & 1,602 & 1,564 & 38 \\
\hline Business & 755 & 742 & 13 \\
\hline Indirect Taxes & 1,772 & 1,738 & 34 \\
\hline Other & 9,776 & 9,697 & 79 \\
\hline Total & 13,905 & 13,741 & 164 \\
\hline \multicolumn{4}{|l|}{$\begin{array}{l}\text { Federal Governemt } \\
\text { Direct Taxes }\end{array}$} \\
\hline People & 3,634 & 3,549 & 85 \\
\hline Business & 2,337 & 2,299 & 38 \\
\hline NR & 82 & 80 & 2 \\
\hline Other & 1,092 & 1,073 & 19 \\
\hline Less Transfer to Alberta & $-1,614$ & $-1,582$ & -32 \\
\hline Net Federal Revenue & 5,531 & 5,419 & 112 \\
\hline
\end{tabular}


Table 7

Relative Contributions of Irrigation Agriculture, Alberta, 1981

\begin{tabular}{lcrr}
\hline \hline Item & $\begin{array}{c}\text { Direct } \\
\text { Contribution }\end{array}$ & $\begin{array}{c}\text { Total } \\
\text { Contribution }\end{array}$ & Ratio \\
\hline Output (millions of dollars) & 693 & 2,492 & 3.60 \\
Value-Added (millions of dollars) & 233 & 940 & 4.03 \\
Imports (millions of dollars) & 102 & 474 & 4.65 \\
Employment (Number) & 18,439 & 35,106 & 1.90 \\
\hline \hline
\end{tabular}

perceived in direct contributions to employment, valueadded, and inter-regional trade. When account is taken of secondary contributions generated by indirect, induced, and industry-scale (agglomeration) effects, a sector such as the irrigation production sector becomes considerably more important. Policy formulation for the primary resource sectors should recognize total contributions, particularly since there is a secular decline in their small direct contributions, and if the latter become the criteria for policy making, there may be a tendency to downplay their needs.

\section{Notes}

${ }^{1}$ Many of the major data sets conceming agriculture were collected for the year 1981. The Census of Agriculture, the Census of Manufacturers, and many major provincial statistics are available only for census years.

${ }^{2} \mathrm{~A}$ rectangular input-output model and the nature of output determination is described by Johnson and Kulshreshtha, 188189.

${ }^{3}$ These four types of imports were non-competitive imports from the Canadian standpoint, non-competitive imports from the Albertan standpoint, competitive imports, and unallocated imports. In relative magnitudes, the competitive imports constituted 97 percent of imports in Alberta during 1981.

4This is a standard derivation of output determination in a rectangular input-output model. For details, see Johnson and Kulshreshtha, Lal, and Matuszewski.

${ }^{5}$ The original data for the Alberta transactions table were prepared by Statistics Canada. However, the Alberta Bureau of Statistics operationalized the model.

${ }^{6}$ For details of the RAS method, see Stone, and McMenamin and Haring.

'The split of agriculture between dryland and irrigation production was based on a total production function approach. The inputs for enterprises under irrigated conditions were classified using the input-output model commodity codes. These data, after being subtracted from the total agricultural vector, represented the dryland production conditions.

${ }^{8}$ An employment multiplier represents a direct plus indirect (and induced) change in the employment of all sectors as a result of a unit change in the final demand of a sector. For details, see Miller and Blair, 111-113.

'All data were obtained from Alberta Treasury publications.

${ }^{10}$ The equations also were estimated using the seemingly unrelated regression estimate method. The relative magnitudes of the coefficients were virtually the same, although the tvalues were slightly higher.

${ }^{11}$ Major irrigated crops include alfalfa and forage crops, such specialty crops as sugar beets, legumes, potatoes, as well as non-traditional cereal crops such as soft wheat. For crops such as alfalfa, sugar beets, and soft wheat, there is no substitution possible through the use of dryland farming methods.

${ }^{12} \mathrm{An}$ alternative to this procedure might have been to use the Statistics Canada Inter-Provincial Input-Output model. One of the serious limitations of this model is a relatively high degree of aggregation for the primary resource and agricultural processing sectors. Since this study focused upon these sectors, the Statistics Canada model was considered somewhat limiting.

${ }^{13}$ Based on a 1979 survey of origin and destinations of interprovincial trade by Statistics Canada.

${ }^{14}$ During the 1969-84 period, governments have spent a total of $\$ 203$ million under the irrigation capital works program, and another $\$ 144$ million under the headworks program, for a total of $\$ 319$ million. This amounts to roughly $\$ 20$ million per annum.

${ }^{19}$ These benefits to other regions would be realized only under the strict assumption that these regions have no substitute market for their products.

\section{References}

Alberta Treasury. Economic Accounts of Alberta, 1981. Edmonton, Alberta: Alberta Treasury, 1982.

Isard, W. and R. E. Kuene. "The Impact of Steel Upon the Greater New York-Philadelphia Urban Industrial Region." Review of Economics and Statistics. 35 (1953). 289-301.

Johnson, T. G. and S. N. Kulshreshtha. "Exogenizing Agriculture in an Input-Output Model to Estimate Relative Impacts of Different Farm Types." Western Journal of Agricultural Economics. 7 (1982). 187-198. 
Lal, K. "Compilation of Input-Output Tables: Canada." Review of Income and Wealth. 28:4 (1982). 411-430.

Matuszewski, T. "Partly Disaggregated Rectangular InputOutput Models and Their Use for the Purpose of a Large Corporation." Input-Output Techniques. A. Brody and A. P. Carter, eds. Amsterdam: North-Holland Publishing Co., 1972.

McMenamin, D. G. and Haring, J. E. "An Appraisal of Nonsurvey Techniques for Estimating Regional Input-Output Models." Journal of Regional Science. 14 (1974). 191-205.
Miller, R. E. and P. D. Blair. Input-Output Analysis: Foundations and Extensions. Englewood Cliffs, N.J.: PrenticeHall Inc., 1985.

Statistics Canada. The Input-Output Structure of the Canadian Economy: 1971-1978. Catalogue No. 15-201E. Ottawa: Statistics Canada, 1979.

Origin and Destination of Goods of Merchandising Establishments. Catalogue No. 63-540. Ottawa: Statistics Canada, 1982.

Stone, R. Input-Output Relationships: 1954-1966. Vol. 3. London: Chapman and Hall, 1963. 